\title{
PENERAPAN PERATURAN PEMERINTAH NOMOR 46 TAHUN 2013 DIBANDINGKAN PELAKSANAAN PAJAK PENGHASILAN PADA PT GLOBAL BINTANG UTAMA JAKARTA
}

\author{
AA Supardi \& Ari Samto \\ Institut Ilmu Sosial Dan Manajemen STIAMI \\ (aa_supardi@stiami.ac.id) dan (arisamto5@gmail.com)
}

\begin{abstract}
Abstrak. Penelitian ini dilakukan untuk mengetahui seberapa besar pengaruh pelaksanaan sebelum dan sesudah diterapkannya Peraturan Pemerintah Nomor 46 Tahun 2013 pada PT Global Bintang Utama Jakarta. Pada pertengahan tahun 2013 Pemerintah mengeluarkan Peraturan Pemerintah Nomor 46 Tahun 2013 yang dikhusukan untuk badan usaha yang memiliki peredaran bruto di bawah Rp. 4.800.000.000 (empat miliar delapan ratus juta rupiah). Peraturan Pemerintah Nomor 46 Tahun 2013 diterbitkan bukan untuk menggantikan Undang-Undang No. 36 Tahun 2008, peraturan ini hanya mengkhususkan bagi usaha kecil menengah (UKM). Pada Undang-Undang Nomor 36 Tahun 2008 dengan Peraturan Pemerintah Nomor 46 Tahun 2013 terdapat perbedaan untuk penghitungan, penyetoran dan pelaporan pajak terutang pada suatu badan usaha dan perbedaaan perlakuan perpajakan pada peraturan tersebut dilihat dari segi kebijakan perpajakan, undang-undang perpajakan dan administrasi perpajakan yang sesuai dengan peraturan perpajakan yang berlaku.
\end{abstract}

Kata Kunci : Pajak Penghasilan, PP 46 Tahun 2013, Unsur Perpajakan

Abstract. This study was conducted to determine how much influence the implementation of the before and after implementation of Government Regulation No. 46 Year 2013 on PT Global Bintang Utama Jakarta. In mid-2013 the Government issued Government Regulation No. 46 Year 2013 is localized for enterprises that have a gross income below Rp.4.800.000.000 (four billion, eight hundred million rupiah). Government Regulation No. 46 Year 2013 issued not to replace Law No. 36 In 2008, these regulations are specialized for small and medium enterprises (SMEs). In Act No. 36 of 2008 by Government Regulation No. 46 Year 2013 there is a difference for the count, deposit and reporting of tax payable on an enterprise and differences in tax treatment, these rules in terms of taxation policy, the tax laws and tax administration in accordance with applicable tax regulations.

Keywords: Income Tax, PP 46 in 2013, Elements of Taxation.

Pembangunan Nasional tidak akan tercapai dengan baik apabila tidak diikuti dengan pendanaan yang berkesinambungan. Oleh karena itu, rakyat bersama-sama dengan Pemerintah bekerja sama dalam mewujudkan tujuan pembangunan nasional dengan mendukung dari segi pendanaan, yaitu dengan adanya pemungutan pajak. Pajak merupakan penerimaan negara terbesar, dari tahun ke tahun jumlah penerimaan negara dari perpajakan dalam Anggaran Pendapatan Belanja Negara (APBN) selalu meningkat.
Penerimaan dalam negeri dalam Anggaran Pendapatan Belanja Negara tahun 2015 target penerimaan pajak yang direncanakan adalah Rp. 1.489,3 Triliun pada tahun 2015 terealisasi sebesar Rp. 1.240,4 Triliun atau penerimaan pajak sebesar $83,3 \%$ dari target yang direncanakan.

Pajak adalah sumber penerimaan negara yang menyumbang pembiayaan untuk pembangunan nasional yang sangat signifikan dan terbesar dari sumber-sumber penerimaan yang lain. Sedangkan pajak bagi perusahaan 
merupakan beban yang dapat mengurangi laba bersih. Keputusan bisnis sebagian besar dipengaruhi oleh pajak, baik secara langsung maupun tidak langsung. Keputusan bisnis yang baik apabila bertemu dengan keputusan pajak hal ini akan menjadi keputusan yang kurang baik, begitu juga sebaliknya.

Pemerintah mengeluarkan Peraturan Pemerintah (PP) pada tahun 2013, yaitu Peraturan Pemerintah Nomor 46 Tahun 2013 tentang Pajak Penghasilan dari usaha yang diterima atau diperoleh Wajib Pajak yang memiliki peredaran bruto tertentu dikenakan Pajak Penghasilan yang bersifat final sebesar $1 \%$ dari peredaran bruto (omzet) setiap bulannya yang tidak melebihi Rp. 4.800.000.000 (empat milyar delapan ratus juta rupiah) dalam satu (1) tahun pajak. Dengan usaha meliputi usaha dagang, industri, dan jasa seperti toko, kios, pakaian, elektronik, bengkel dan usaha lainnya. Peraturan Pemerintah Nomor 46 Tahun 2013 mulai diberlakukan di Indonesia sejak 01 Juli 2013.

Tujuan dari peraturan ini adalah untuk memberikan kemudahan kepada Wajib Pajak yang menerima atau memperoleh penghasilan dari usaha yang memiliki peredaran bruto tertentu, untuk melakukan perhitungan, penyetoran, dan pelaporan pajak penghasilan yang terutang. Sebelum dikeluarkannya Peraturan Pemerintah Nomor 46 Tahun 2013, perusahaan masih menggunakan tarif pajak pasal 31 E Undang-Undang Nomor 36 Tahun 2008 pada tahun 2013 dan tahun 2015. Dalam hal perpajakan PT Global Bintang Utama Jakarta telah berusaha melaksanakan kewajiban perpajakannya.

Permasalahan yang muncul sehubungan dengan penurunan omzet pada perusahaan pada tahun pajak 2015 menyebabkan beban pajak terutang menjadi lebih tinggi dikarenakan perhitungan tersebut menggunakan acuan pasal 31E UndangUndang Pajak Penghasilan Nomor 36 Tahun 2008 dengan peredaran bruto di bawah Rp. 4.800.000.000,- .

Fenomena yang ditemukan pada penelitian ini adalah penurunan omzet menyebabkan pembayaran pajak pada PT Global Bintang Utama Jakarta pada tahun
2015 menjadi lebih tinggi, sedangkan pada tahun tersebut peredaran bruto pada perusahaan tersebut dikategorikan di bawah batas peredaran bruto Peraturan Pemerintah Nomor 46 Tahun 2013, yaitu kurang dari Rp. 4.800.000.000,- per tahun.

Berdasarkan latar belakang yang telah dipaparkan di atas, penulis mengambil judul penelitian mengenai "Penerapan Peraturan Pemerintah Nomor 46 Tahun 2013 Dibandingkan Pelaksanaan UndangUndang Pajak Penghasilan Pada PT Global Bintang Utama Jakarta".

\section{KAJIAN LITERATUR}

Menurut Abdul Rahman (2010: 183) administrasi pajak adalah sebagai berikut : "Pentatausahaan dan pelayanan terhadap kewajiban-kewajiban dan hak-hak Wajib Pajak baik pentatausahaan dan pelayanan tersebut dilakukan di kantor Fiskus maupun di kantor Wajib Pajak".

Menurut pakar perpajakan Mansury (1994: 37-47) dalam sistem perpajakan dikenal tiga unsur perpajakan, yaitu:

1. Kebijaksanaan Perpajakan (Tax Policy)

Kebijaksanaan perpajakan merupakan alternatif dari berbagai sasaran yang hendak dituju dalam sistem perpajakan. Alternatif-alternatif tersebut meliputi :

a. Pajak apa yang akan dipungut?

b. Siapa yang akan dijadikan Subjek Pajak?

c. Apa saja yang merupakan Objek Pajak?

d. Berapa besar tarif pajak?

e. Dan bagaimana prosedurnya?

Setelah sasaran ditentukan barulah dirumuskan kebijaksanaan yang akan ditempuh dalam sistem perpajakan tersebut.

2. Undang-Undang Perpajakan (Tax Law)

Yang dimaksud dengan UndangUndang Perpajakan adalah seperangkat 


\section{REFORMASI ADMINISTRASI}

Jurnal Ilmiah Untuk Mewujudkan Masyarakat Madani ISSN 2355-309X

peraturan perpajakan yang terdiri dari undang-undang beserta peraturan pelaksanaannya. Undang-Undang Perpajakan merupakan salah satu unsur dari sistem perpajakan. Dalam undangundang perpajakan diatur mengenai pokok-pokok pikiran yang bersifat prinsip serta peraturan pelaksanaannya, berupa Peraturan Pemerintah, Keputusan Presiden, Keputusan Menteri dan seterusnya.

3. Administrasi Perpajakan (Tax Administration)

Administrasi perpajakan merupakan salah satu dari ketiga unsur perpajakan. Administrasi perpajakan sendiri mempunyai tiga pengertian, yaitu:

a. Suatu instansi atau badan yang diberi wewenang dan tanggung jawab untuk menyelenggarakan pungutan pajak. Di Indonesia, organisasi atau badan yang menyelenggarakan pungutan pajak Negara berada di bawah Departemen Keuangan, yaitu Direktorat Jenderal Pajak, dan Direktorat Jenderal Bea dan Cukai.

b. Orang-orang yang terdiri dari pejabat dan pegawai yang bekerja pada instansi perpajakan yang secara nyata melaksanakan kegiatan pungutan pajak.

c. Kegiatan penyelenggaraan pungutan pajak oleh suatu instansi atau badan yang ditatalaksanakan sedemikian rupa sehingga dapat mencapai sasaran yang telah digariskan dalam kebijaksanaan perpajakan, berdasarkan sarana hukum yang ditentukan oleh undang-undang perpajakan.

Dasar-dasar bagi terselenggaranya administrasi perpajakan yang baik meliputi berikut ini: a. Kejelasan dan kesederhanaan dari ketentuan undang-undang yang memudahkan bagi administrasi dan memberi kejelasan bagi Wajib Pajak.

b. Kesederhanaan akan mengurangi penyeludupan pajak. Kesederhanaan dimaksud baik dalam perumusan yuridis, yang memberikan kemudahan untuk dipahami; maupun kesederhanaan untuk dilaksanakan oleh aparat dan pemenuhan kewajiban oleh Wajib Pajak.

c. Reformasi dalam bidang perpajakan yang realistis harus mempertimbangkan kemudahan tercapainya efisiensi dan efektivitas administrasi perpajakan, semenjak dirumuskannya kebijaksanaan perpajakan.

d. Administrasi perpajakan yang efisien dan efektif perlu disusun dengan memperhatikan pengaturan pengumpulan, pengolahan dan pemanfaatan informasi tentang subjek pajak dan objek pajak.

Kegiatan administrasi perpajakan mencakup kegiatan-kegiatan, antara lain:

a. Penelitian, pemeriksaan dan penyidikan.

b. Penerbitan Surat Ketetapan Pajak atau Surat Ketetapan Pajak Tambahan.

c. Penerapan sanksi.

d. Penyelesaian surat keberatan dan penyusunan risalah banding.

e. Penagihan.

Dari uraian unsur-unsur perpajakan yang sudah dikemukan oleh pakar perpajakan maka dapat disimpulkan oleh penulis bahwa ketiga unsur tersebut terjadi menurut proses sesuai dengan urutan waktu penyusunan sistem perpajakan yang bersangkutan. Ketiga unsur tersebut saling berkaitan satu dengan 
A. A Supardi \& Ari Samto, Penerapan Peraturan Pemerintah Nomor 46 Tahun 2013...

lainnya dan tidak dapat dipisahkan secara urutan maupun fungsinya.

Pajak merupakan salah satu sumber penerimaan dana yang sangat potensial yang digunakan oleh pemerintah sebagai sumber pembiayaan dalam menyelenggarakan roda pemerintah yang diharapkan dapat mengurangi ketergantungan Negara kita terhadap hutang luar negeri.

Menurut S.I Djajadiningrat (Siti Resmi, 2012: 1),"Pajak sebagai suatu kewajiban menyerahkan sebagian dari kekayaan ke kas Negara yang disebabkan suatu keadaan, kejadian dan perbuatan yang memberikan kedudukan tertentu, tetapi bukan sebagai hukuman, menurut peraturan yang ditetapkan pemerintah serta dapat dipaksakan, tetapi tidak ada jasa timbal balik dari Negara secara langsung, untuk memelihara kesejahteraan secara umum".

Menurut P.J.A Adriani (Diana Sari, 2013: 34),"Pajak adalah iuran masyarakat kepada negara (yang dapat dipaksakan) yang terutang oleh yang wajib membayarnya menurut peraturan-peraturan umum (undangundang) dengan tidak mendapat prestasi kembali yang langsung dapat ditunjuk dan yang gunanya adalah untuk membiayai pengeluaran-pengeluaran umum berhubungan tugas negara untuk menyelenggarakan pemerintahan".

Syarat-syarat pemungutan pajak dalam buku Mardiasmo (2011: 2), antara lain:

1. Pemungutan pajak harus adil (Syarat Keadilan)

Pemungutan pajak yang dikenakan secara adil dan melihat kemampuan Wajib Pajak dalam membayar pajak.

2. Pemungutan pajak harus berdasarkan undang-undang (Syarat Yuridis)

Pemungutan pajak yang diatur dalam pasal 23 ayat 2 Undang-Undang Dasar 1945 untuk memberikan jaminan hukum yang adil baik bagi negara maupun Warga Negara Indonesia.
3. Tidak mengganggu perekonomian (Syarat Ekonomis)

Pemungutan pajak harus menjaga keseimbangan kehidupan perekonomian dan tidak mengganggu kehidupan ekonomi Wajib Pajak.

4. Pemungutan pajak harus efisien (Syarat Finansial)

Pemungutan pajak harus dapat ditekan sehingga biaya pemungutan pajak tidak terlalu besar.

5. Sistem pemungutan pajak harus sederhana Pemungutan pajak dilakukan secara sederhana yang berguna bagi masyarakat dalam memenuhi kewajiban perpajakannya.

Norma Penghitungan Penghasilan Neto adalah norma yang dapat digunakan oleh wajib pajak dalam penghitungan penghasilan neto dalam satu tahun pajak sebagai dasar penghitungan $\mathrm{PPh}$ Pasal 25/29 terutang.

Wajib Pajak yang diperbolehkan menggunakan Norma Penghitungan Penghasilan Neto dalam menghitung penghasilan neto dalam satu tahun untuk penghitungan PPh Pasal 25/29 adalah hanya Wajib Pajak Orang Pribadi yang telah memenuhi syarat, yaitu:

1. Wajib Pajak Orang Pribadi yang mempunyai peredaran bruto atau omzet bruto kurang dari Rp.4.800.000.000,dalam satu tahun pajak (Pasal 14 UU no.36 Tahun 2008 tentang $\mathrm{PPh}$ dan PP nomor 46 Tahun 2013)

Ketentuan tersebut berlaku sejak tahun pajak 2007.

2. Khusus mulai bulan Juli 2013 penggunaan Norma Penghitungan Penghasilan Neto sesuai dengan PP Nomor 46 Tahun 2013.

3. Wajib Pajak Orang Pribadi yang bermaksud menggunakan Norma Penghitungan Penghasilan Neto dalam menghitung penghasilan neto wajib memberitahuan kepada Direktur Jenderal Pajak (Kantor Pelayanan Pajak) dalam 
jangka waktu 3 (tiga) bulan pertama dari tahun pajak bersangkutan (dapat didownload di Formulir Pemberitahuan Penggunaan Norma Penghitungan Neto).

Menurut Ratna Anjarwati (2013: 59), "Pengenaan PPh Final pada umumnya dilakukan dengan mekanisme pemotongan dan penyetoran oleh pihak pemberi penghasilan. Apabila pihak pemberi penghasilan bukan pemotong pajak atau tidak melakukan pemotongan pajak, maka mekanisme $\mathrm{PPh}$ Final mewajibkan Wajib Pajak menerima penghasilan tersebut untuk melakukan penyetoran sendiri. Pemotongan atau penyetoran sendiri ini harus dilakukan pada setiap bulan (masa pajak) saat penghasilan itu dibayarkan atau terutang (jika dilihat dari sisi pemberi penghasilan) atau saat penghasilan tersebut diterima atau diperoleh (jika dilihat dari sisi penerima penghasilan)".

Ratna Anjarwati (2013: 60) mengemukakan bahwa PP Nomor 46 Tahun 2013 adalah : "Pada Juli 2013 lalu, Pemerintah menggulirkan Peraturan Pemerintah (PP) Nomor 46 Tahun 2013 yang berisi tentang ketentuan mengenai pengenaan $\mathrm{PPh}$ Final terhadap Wajib Pajak yang memiliki peredaran bruto atau omzet dalam jumlah tertentu".

Sesuai dengan ketentuan Pasal 2 ayat (2) huruf b PP tersebut, jumlah tertentu yang dimaksud adalah tidak melebihi Rp. 4.800.000.000,- dalam satu tahun pajak. Dalam istilah sehari-hari Wajib Pajak yang omzet atau peredaran brutonya tidak melebihi Rp. 4.800.000.000,- ini sering disebut dengan Wajib Pajak Usaha Kecil dan Menengah.

Dasar hukum Peraturan Pemerintah Nomor 46 Tahun 2013 adalah:

1. Pasal 4 ayat (2) huruf e Undang-Undang Pajak Penghasilan. Atas penghasilan tertentu lainnya dapat dikenakan Pajak Penghasilan (PPh) yang bersifat final yang diatur dengan atau berdasarkan Peraturan Pemerintah.

2. Pasal 17 ayat (7) Undang-Undang Pajak Penghasilan. Dengan Peraturan

Pemerintah dapat ditetapkan tarif pajak tersendiri atas penghasilan tertentu yang pajaknya bersifat final. Tarif tersebut tidak boleh melebihi tarif tertinggi Pajak Penghasilan Orang Pribadi. Penentuan tarif pajak tersendiri tersebut didasarkan atas pertimbangan kesederhanaan, keadilan, dan perluasan partisipasi dalam pembayaran pajak.

Maksud dikeluarkannya Peraturan Perpajakan melalui Peraturan Pemerintah Nomor 46 Tahun 2013 ini adalah:

1. Memberikan kemudahan dan penyederhanaan aturan perpajakan.

2. Mengedukasi masyarakat untuk tertib beradministrasi.

3. Mengedukasi masyarakat untuk transparansi.

4. Memberikan kesempatan masyarakat untuk berkontribusi dalam penyelenggaraan Negara.

Sedangkan tujuan dari Peraturan Pemerintah Nomor 46 Tahun 2013 ini adalah:

1. Memudahkan bagi masyarakat dalam melaksanakan kewajiban perpajakan.

2. Meningkatkan pengetahuan tentang manfaat perpajakan bagi masyarakat.

3. Terciptanya kondisi kontrol sosial dalam memenuhi kewajiban perpajakan.

\section{METODE PENELITIAN}

Menurut Sugiyono (2014: 38) mendefinisikan metode peneltian kualitatif dapat diartikan sebagai: "Metode penelitian yang berlandaskan pada filsafat postpositivisme atau enterpretif, digunakan untuk meneliti pada kondisi objek yang alamiah, (sebagai lawannya adalah eksperimen)dimana peneliti adalah instrumen 
kunci, teknik pengumpulan data dilakukan secara triangulasi (gabungan), analisis data bersifat induktif dan hasil penelitian kualitatif lebih menekankan makna dari pada generalisasi”.

Dalam penelitian ini, teknik analisis yang digunakan adalah deskriptif kualitatif. Untuk memperoleh jawaban atas pertanyaan penelitian, penulis mengumpulkan data-data yang didapat melalui studi kepustakaan, data sekunder, maupun wawancara mendalam dengan informan. Dalam analisis ini, penulis hanya memilih data yang penting dan relevan yang terkait dengan permasalahan penelitian, menganalisis data tersebut dan menafsirkannya untuk mendapatkan suatu pemahaman mengenai penerapan Peraturan Pemerintah Nomor 46 Tahun 2013. Serta dengan menggunakan analisis deskriptif comparative yakni suatu analisis yang menguraikan dan membandingkan perhitungan pajak penghasilan badan menurut kedua peraturan perpajakan yang sesuai dengan Undang-Undang Perpajakan yang berlaku.

Untuk menilai apakah data yang diperoleh dari lapangan merupakan data yang valid dan reliable, maka diperlukan penilaian validitas dan reliabilitas data melalui empat kriteria, yaitu:

1. Kriteria Kredibilitas (Kepercayaan)

Dalam rencana penelitian, penulis menggunakan Kriteria Kredibilitas (kepercayaan), hal ini penulis paparkan agar data-data yang diperoleh dapat dipercaya. Data hasil penelitian dapat dikatakan telah mencapai tingkat kepercayaan apabila memenuhi unsur keterlibatan dengan data-data perusahaan yang penulis dapatkan.Kriteria Kredibilitas ini, mengharuskan penulis untuk terjun langsung ke lapangan untuk melakukan wawancara yang bersumberkan pada data yang penulis dapatkan. Dengan adanya wawancara tersebut, maka akan mempererat hubungan antara penulis dengan narasumber sehingga semakin besar kemungkinan keterbukaan mengenai informasi-informasi yang diberikan dan kecil kemungkinan narasumber menyembunyikan informasi-informasi yang sulit penulis dapatkan.

2. Kriteria Transferabilitas (Dapat Dialihkan)

Uji Transferabilitas dilakukan dengan membuat laporan penelitian yang dapat memberikan uraian dengan rinci, jelas, sistematis, dan dapat dipercaya. Dalam hal ini, peneliti akan menerapkan hasil penelitian di PT Global Bintang Utama Jakarta. Berdasarkan hasil penelitian yang diperolah, maka hasil tersebut digunakan untuk memperbaiki atau menjelaskan alur yang sebenarnya atas Implementasi kebijakan PP 46 Tahun untuk dijadikan acuan untuk pemenuhan kewajiban perpajakan. Pada kriteria ini, dimaksudkan bahwa hasil penelitian yang diperoleh dapat dimengerti oleh perusahaan dan dapat diterapkan sebagai salah satu upaya memberikan kemudahan untuk pemahaman mengenai PP 46 Tahun 2013.

3. Kriteria Dependabilitas (Dapat Diandalkan)

Kriteria Dependabilitas dilakukan dalam penelitian kualitatif, di tujukan agar orang lain dapat mengulang proses penelitian yang dilakukan peneliti dengan melihat secara langsung atau memperhatikan secara langsung apa-apa saja yang dilakukan oleh penulis dalam melakukan penelitian sehingga dapat menghasilkan hasil penelitian yang kemudian dapat dimanfaatkan oleh orang lain.

4. Kriteria Konfirmabilitas (Dapat Ditegaskan)

Pengujian hasil penelitian terletak pada kriteria Konfirmabilitas (dapat ditegaskan). Penelitian dapat dikatakan objektif jika hasil peneltian yang diperoleh, dilakukan melalui berbagai proses yakni, mengumpulkan data-data terkait dengan kebijakan PP 46 Tahun 2013 kemudian melakukan wawancara terbuka kepada narasumber-narasumber terkait dalam hal ini adalah pegawai pajak perusahaan, konsultan pajak dan pihak akademisi, kemudian dilanjutkan dengan menganalisis data serta hasil penelitian 
yang dituangkan pada hasil penelitian ini bertujuan untuk mendapatkan hasil penelitian yang tentunya disepakati oleh pihak-pihak yang terkait.

\section{PEMBAHASAN}

Berdasarkan informan 1 yang bekerja pada perusahaan tesebut, yang telah dilakukan wawancara secara mendalam didapat beberapa poin penting mengenai penjelasan tentang pemenuhan kewajiban pajak apabila menggunakan tarif pajak umum yang sesuai dengan Undang Undang Pajak Penghasilan Nomor 36 Tahun 2008 dengan Peraturan Pemerintah Nomor 46 Tahun 2013 adalah:

1. Informan menjelaskan bahwa acuan perhitungan pajak menggunakan tarif pasal 31E dan tarif pasal 17 UU PPh 36 Tahun 2008 dinilai lebih rumit.

2. Informan menjelaskan bahwa penggunaan acuan UU PPh No. 36 Tahun 2008, perusahaan harus melakukan pembukuan yang lengkap dan terinci, ini akan menyulitkan apabila perusahaan berpenghasilan atau beromzet tidak menentu.

3. Informan menjelaskan bahwa dengan menggunakan acuan yang terdapat pada PP 46 Tahun 2013 untuk perhitungan pajak dinilai lebih simpel atau sederhana. Ini dikarenakan bahwa pada PP 46 Tahun 2013 menegaskan bahwa penghasilan dibawah Rp. 4.800.000.000,- per tahun, untuk perhitungan pajaknya hanya dikenakan tarif $1 \%$ dari omzet tersebut.

4. Informan menjelaskan bahwa pada PP 46 Tahun 2013 apabila perusahaan mengalami kerugian, maka kerugian tersebut tidak bisa digunakan untuk pengurang pajak atau kerugian tersebut dikompensasikan ke tahun pajak berikutnya.

5. Informan menjelaskan bahwa pada PP 46 Tahun 2013 tidak mengenal untung atau rugi, sehingga apabila mengalami kerugian tetap dikenakan pajak yaitu sebesar tarif yang ada pada PP 46 Tahun 2013 sebesar $1 \%$.

6. Pemahaman perundang-undangan pajak diakui oleh informan tidak sepenuhnya dimengerti dan dipahami. Sehingga dimungkinkan terdapat kesalahan dalam hal perhitungan, penyajian dan pelaporan pajaknya.

Dari hasil penjelasan yang didapat dari informan yang bekerja pada perusahaan tersebut, penulis dapat menganalisis bahwa perusahaan yang sudah menjadi Pengusaha Kena Pajak (PKP) dan berbadan hukum yang memiliki omzet tidak menentu dalam hal ini masih di bawah peredaran bruto sebesar Rp. 4.800.000.000,- maka sebaiknya menggunakan acuan pajak penghasilan final sebesar $1 \%$ bukan menggunakan acuan tarif pajak pasal 31E Undang-Undang Pajak Penghasilan Tahun 2008. Perusahaan wajib melakukan pembukuan walaupun omzet belum melebihi dari peredaran bruto, ini dapat memudahkan dalam perhitungan, penyusunan, penyajian dan pelaporan kewajiban pajak yang akan dibayarkan dan dilaporkan pada akhir masa tahun pajak.

Penggunaan PP 46 Tahun 2013 pada perusahaan ini dinilai efektif dikarenakan acuan yang terdapat pada peraturan tersebut lebih mudah yakni hanya dihitung berdasarkan $1 \%$ dari peredaran bruto. Sehingga didapat pajak yang relatif lebih kecil apabila dibandingkan dengan tarif yang ada pada UU PPh No. 36 Tahun 2008. Kelemahan dalam peraturan ini dijelaskan pada informan bahwa kompensasi kerugian tidak dapat dikompensasikan sebagai pengurang pajak dan tidak adanya kredit pajak maupun pengurang PTKP dalam acuan PP 46 Tahun 2013. Perusahaan tetap dikenakan pajak walaupun perusahaan tersebut sedang mengalami kerugian.

Pelaksanaan peraturan perpajakan yang ada di Indonesia tidak akan berjalan dengan baik apabila tidak didukung dengan peranserta lembaga pemungutan pajak untuk 
A. A Supardi \& Ari Samto, Penerapan Peraturan Pemerintah Nomor 46 Tahun 2013...

mensosialisasikan peraturan-peraturan tersebut. Dalam hal ini peneliti juga melakukan wawancara dengan pihak informan yang bekerja sebagai Konsultan Pajak.

Setelah dilakukan wawancara dengan pihak Konsultan Pajak sebagai Informan 2 didapat informasi mengenai penjelasanpenjelasan yang terdapat pada peraturan perpajakan secara umum dan mengenai Peraturan Pemerintah Nomor 46 Tahun 2013 secara khusus terperinci sebagai berikut:

1. Informan menyatakan bahwa sosialisasi pelaksanaan PP 46 Tahun 2013 sudah dilakukan secara merata dan menyeluruh sebelum peraturan tersebut diterbitkan.

2. Informan menjelaskan bahwa mekanisme perhitungan pada PP 46 Tahun 2013 cukup mudah yakni hanya dikalikan $1 \%$ dari peredaran bruto atau omzet yang didapat. Dan untuk pembayaran bisa dilakukan di bank dengan menggunakan ID Billing. Serta pelaporan juga sudah bisa dilaporkan secara online.

3. Informan menjelaskan bahwa apabila perusahaan sudah telanjur menggunakan acuan perhitungan pasal 25 dan seharusnya menggunakan acuan PP 46 Tahun 2013 adalah hanya melakukan pemindahbukuan saja.

4. Informan menjelaskan bahwa apabila sudah melakukan pelaporan PPh 25 maka tidak usah melakukan pemindahbukuan. Pihak KPP atau AR masing-masing sudah bisa mengetahui dari hasil pelaporan pada masa yang nihil tersebut.

5. Informan menjelaskan bahwa pembukuan atau pencatatan itu bersifat optional akan tetapi apabila sudah memiliki peredaran bruto atau omzet yang cukup besar sebaiknya melakukan pembukuan, ini dikarenakan pembukuan lebih membantu pada saat pembuatan laporan tahunan pajak. Pembukuan sebaiknya dilakukan oleh perusahaan atau badan yang sudah berbadan hukum dan sudah menjadi bagian dari PKP.

6. Informan menjelaskan bahwa penerimaan dari pajak penghasilan secara final dalam hal ini penerimaan dari diberlakukannya PP 46 Tahun 2013 cukup signifikan, mengingat pertumbuhan perusahaan atau badan yang mulai berdiri cukup banyak.

7. Informan menjelaskan bahwa apabila wajib pajak yang sudah menggunakan acuan PP 46 Tahun 2013 jika mengalami kerugian maka kerugian tersebut tidak dapat dikompensasikan sebagai kredit pajak atau pengurang pajak, ini dikarenakan tarif pajak yang dikenakan sudah relatif kecil, yakni $1 \%$ dari omzet.

8. Informan menjelaskan bahwa dalam PP 46 Tahun 2013 pengurang pajak tidak diperkenankan walaupun pengurang tersebut berupa PTKP.

9. Informan menjelaskan bahwa diskriminasi terhadap PP 46 Tahun 2013 mungkin ada namun ini akan dijadikan pertimbangan dalam pembuatan kebijakan selanjutnya.

Dari penjelasan tersebut dapat disimpulkan oleh penulis bahwa dalam PP 46 Tahun 2013 sudah dilakukan sosialisasi sebelum PP 46 Tahun 2013 tersebut diberlakukan mulai Juli tahun 2013. PP 46 Tahun 2013 secara rinci tidak dijelaskan informasi-informasi secara jelas sehingga dapat mengakibatkan Wajib Pajak belum banyak mengetahui dan paham akan isi peraturan tersebut.

Beberapa penjelasan-penjelasan dari kedua informan yang sudah memberikan informasi, penulis juga melakukan wawancara dengan Informan 3 yang berasal dari kalangan akademisi yang ahli dalam bidang perpajakan guna memperoleh informasi yang lebih mendalam.

Terdapat beberapa penjelasan yang disampaikan oleh informan 3 sebagai berikut:

1. Informan menjelaskan bahwa pelaksanaan PP 46 Tahun 2013 sudah dilaksanakan dengan baik akan tetapi masih diperlukan evaluasi terhadap peraturan tersebut. 


\section{REFORMASI ADMINISTRASI}

Jurnal Ilmiah Untuk Mewujudkan Masyarakat Madani ISSN 2355-309X

2. Informan menjelaskan bahwa PP 46 Tahun 2013 belum bisa mengakomodasi bagi WP yang mempunyai omzet dibawah Rp. 4.800.000.000,- ini dikarenakan masih terdapat kelemahan-kelemahan pada peraturan tersebut.

3. Informan menjelaskan bahwa dalam PP 46 Tahun 2013 tidak terdapat diskriminasi ini dikarenakan peraturan tersebut dibuat untuk memudahkan Wajib Pajak untuk melakukan pembayaran pajak.

4. Informan menjelaskan bahwa PP 46 Tahun 2013 tidak berbicara mengenai keadilan melainkan kepatuhan karena dalam menimbangnya berbicara untuk mendorong memudahkan dan patuh membayar pajak.

5. Informan menjelaskan bahwa PP 46 Tahun 2013 merupakan turunan dari undang-undang dilihat dari unsur Tax Law yang terdiri dari kepatuhan dan persamaan hak dan kewajiban Wajib Pajak. Dilihat dari unsur Tax Policy, kebijakan akan menyebabkan sifat memaksa dari pajak realtif semakin semu yang akan menyebabkan Wajib Pajak untuk patuh terhadap pajak. Dari segi Tax
Administration PP 46 Tahun 2013 secara pelaksanaan sudah baik namun masih diperlukan evaluasi.

6. Informan menjelaskan bahwa PP 46 Tahun 2013 masih terdapat inkonsistensi antar pasal-pasal yang ada didalamnya. Atau bisa dikatakan peraturan yang dibuat belum konsisten.

7. Informan menjelaskan bahwa di negara ini sudah terdapat Badan Pembuat Peraturan. Diakui bahwa masih terdapat peraturan yang masih tidak jelas sehingga masih diperlukan perbaikan secara berkesinambungan.

Dari penjelasan informan tersebut dapat disimpulkan penulis bahwa dalam peraturan yang dibuat oleh pemerintah dalam hal ini PP 46 Tahun 2013 secara umum peraturan yang sudah dibuat sudah bagus atau baik akan tetapi dalam pelaksanaannya masih diperlukan evaluasi.

Dari data yang dianalisis oleh penulis berdasarkan laporan SPT Tahunan Badan PT Global Bintang Utama Jakarta dari tahun 2013 sampai dengan tahun 2015, dapat diuraikan secara ringkas dalam bentuk tabel sebagai berikut:

Tabel. 1. Laporan SPT Tahunan Badan PT Global Bintang Utama Jakarta

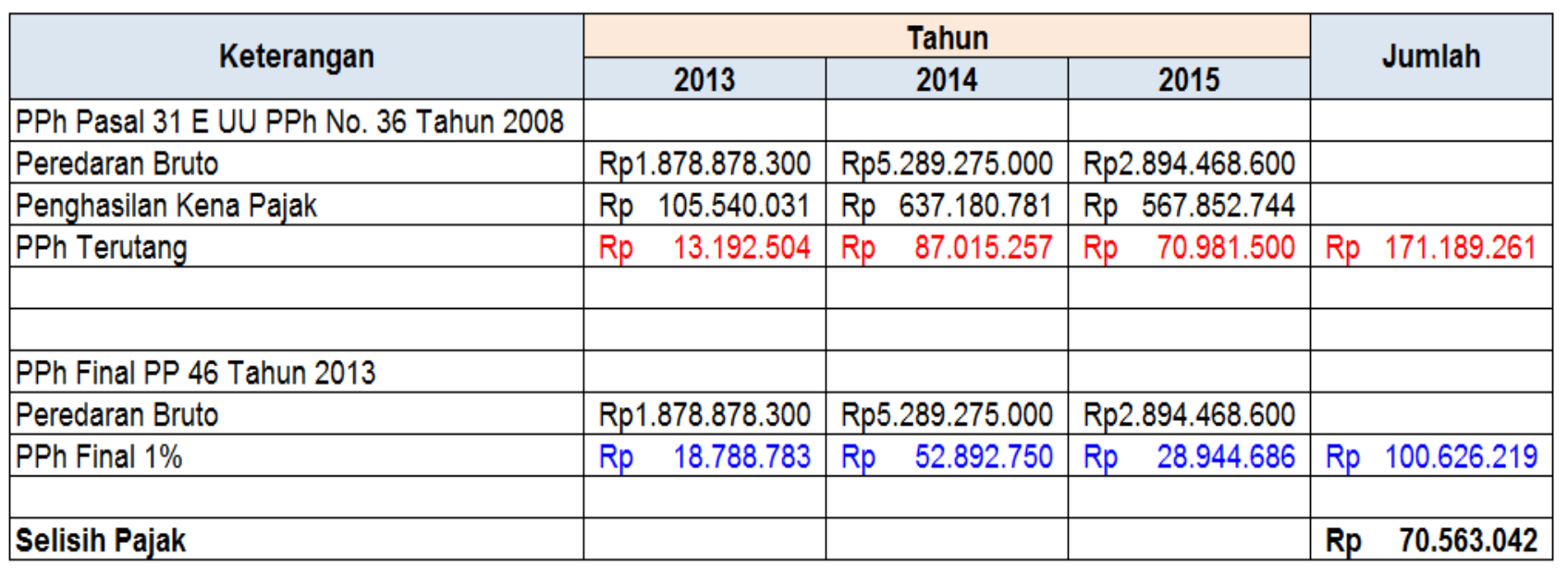

Sumber : Data Diolah Penulis 
A. A Supardi \& Ari Samto, Penerapan Peraturan Pemerintah Nomor 46 Tahun 2013...

Dari data tabel diatas dapat disimpulkan oleh penulis bahwa dari tahun 2013 sampai dengan tahun 2015 total pajak yang dibayarkan oleh perusahaan tersebut adalah sebesar Rp. 171.189.261,- berdasarkan acuan Undang-Undang PPh Nomor 36 Tahun 2008 dengan tarif pajak pasal 31E memberikan dampak pembayaran pajak yang lebih besar atau tinggi, mengingat dari masing-masing tahun pajak tersebut masih terdapat golongan pada peredaran bruto Rp. 4.800.000.000,- per tahun.

Sedangkan dengan perhitungan yang mengacu pada perhitungan menggunakan dasar PP 46 Tahun 2013 dengan ketentuan peredaran bruto dikalikan dengan tarif $1 \%$ berlaku dengan omzet atau peredaran bruto dibawah Rp. 4.800.000.000,- per tahun didapatkan hasil lebih rendah atau kecil dari kewajiban pembayaran pajaknya yakni sebesar Rp. 100.626.219,-.

Dari data perbandingan perhitungan pajak selama 3 tahun berturut-turut, pajak yang dapat ditekan atau dihemat apabila perusahaan menggunakan acuan PP 46 Tahun 2013 sebagai dasar perhitungan kewajiban pajaknya adalah sebesar Rp.70.563.042,--.

Penentuan untuk menggunakan dasar perhitungan yang sesuai dengan peraturan perpajakan yang berlaku, maka kewajiban penggunaan PP 46 Tahun 2013 adalah merupakan sebuah kewajiban dan bukan merupakan alternatif atau pilihan dalam menentukan besaran perhitungan pajak menggunakan peraturan perpajakan yang berlaku. Dalam ini perusahaan tersebut masih dikategorikan perusahaan yang memiliki peredaran bruto tertentu dengan omzet masih dibawah Rp. 4.800.000.000,- per tahun pada tahun pajak 2015 sehingga penggunaan PP 46 Tahun 2013 dinilai tepat atau wajib digunakan oleh perusahaan pada tahun pajak 2016 agar beban pajak yang dibayarkan lebih efektif dan efisien serta dapat menekan pembayaran beban pajak yang tinggi atau besar per tahunnya.

Pada Undang-Undang Ketentuan Umum dan Tata Cara Perpajakan di Indonesia yang dimuat pada pasal 28 UU KUP menegaskan sebagai berikut:
1. Pasal 28 ayat (1): Wajib Pajak Orang Pribadi yang melakukan kegiatan usaha atau pekerjaan bebas dan Wajib Pajak Badan di Indonesia wajib menyelenggarakan pembukuan.

2. Pasal 28 ayat (2): Wajib Pajak yang dikecualikan dari kewajiban menyelenggarakan pembukuan sebagaimana dimaksud pada ayat (1), tetapi wajib melakukan pencatatan, adalah Wajib Pajak Orang Pribadi yang melakukan kegiatan usaha atau pekerjaan bebas yang sesuai dengan ketentuan peraturan perundang-undangan perpajakan diperbolehkan menghitung penghasilan neto dengan menggunakan Norma Penghitungan Penghasilan Neto dan Wajib Pajak Orang Pribadi yang tidak melakukan kegiatan usaha atau pekerjaan bebas.

Dari kedua kutipan yang berasal dari UU KUP secara jelas dikatakan bahwa Wajib Pajak yang melakukan kegiatan usaha atau pekerjaan bebas baik orang pribadi maupun badan wajib menyelenggarakan pembukuan. Hal yang berbeda terdapat pengecualian bagi Wajib Pajak tertentu yang tidak menyelenggarakan pembukuan namun tetap diwajibkan membuat pencatatan.

Namun diberikan pengecualian bagi Wajib Pajak orang pribadi yang melakukan kegiatan usaha atau pekerjaan bebas. Dikecualikan dari kewajiban menyelenggarakan pembukuan tetapi wajib melakukan pencatatan. Konsekuensi bagi Wajib Pajak yang melakukan pencatatan adalah dalam menghitung penghasilan netonya menggunakan NPPN (pasal 28 ayat 2 UU KUP).

Norma Penghitungan adalah pedoman untuk menentukan besarnya penghasilan neto yang diterbitkan oleh Direktur Jenderal Pajak dan disempurnakan terus-menerus (penjelasan pasal 14 ayat 1 Undang-Undang Nomor 36 tahun 2008 tentang Pajak Penghasilan).

Penggunaan Norma Penghitungan tersebut pada dasarnya dilakukan dalam hal:

1. tidak terdapat dasar penghitungan yang lebih baik, yaitu pembukuan yang lengkap; atau 
Jurnal Ilmiah Untuk Mewujudkan Masyarakat Madani

ISSN 2355-309X

2. pembukuan atau catatan peredaran bruto Wajib Pajak ternyata diselenggarakan secara tidak benar.

Norma Penghitungan ini diharapkan akan membantu Wajib Pajak yang belum mampu menyelenggarakan pembukuan untuk menghitung penghasilan neto.

Menurut Undang-Undang PPh Nomor 36 Tahun 2008 ini yang diperbolehkan untuk menghitung penghasilan neto dengan menggunakan NPPN adalah Wajib Pajak orang pribadi yang melakukan kegiatan usaha atau pekerjaan bebas yang peredaran brutonya dalam satu tahun kurang dari Rp4.800.000.000,00 (empat miliar delapan ratus juta rupiah), dengan syarat memberitahukan kepada Direktur Jenderal Pajak dalam jangka waktu tiga bulan pertama dari tahun pajak yang bersangkutan (sesuai pasal 14 ayat 2 Undang-Undang $\mathrm{PPh}$ tahun 2008).

Wajib Pajak Badan diwajibkan menyelenggarakan pembukuan sebagaimana dimaksud pasal 28 ayat 1 Undang-Undang KUP 2009.

Sejak Keputusan Direktur Jenderal Pajak No. Kep.01/PJ./1991 dan Kep.02/PJ.1991 (yang memperbolehkan Wajib Pajak Badan menggunakan NPPN) dinyatakan tidak berlaku seiring dengan berlakunya Kep.536/PJ./2000, dan terhadap Wajib Pajak Badan tidak diperbolehkan menggunakan NPPN, baik saat Wajib Pajak mengisi Surat Pemberitahuannya maupun saat Pemeriksa Pajak menghitung penghasilan kena pajak secara jabatan.

Dari uraian-uraian yang dijelaskan oleh penulis mengenai pembukuan dan pencatatan dapat disimpulkan bahwa PP 46 Tahun 2013 belum sesuai dengan kedua pasal tersebut (Pasal 28 UU KUP dan Pasal 14 UU PPh) menghitung PPh Badan berdasarkan hasil dari pembukuan.

Pelaksanaan PP 46 Tahun 2013 tidak terlepas dari peraturan tambahan yang digunakan untuk proses pelaksanaan peraturan tersebut agar berjalan baik, peraturan tambahan yang dimaksud dalam hal ini adalah Surat Edaran Direktur Jenderal
Pajak SE:-42/PJ/2013 mengenai "Pelaksanaan Peraturan Pemerintah Nomor 46 Tahun 2013 Tentang Pajak Penghasilan Atas Penghasilan Dari Usaha Yang Diterima Atau Diperoleh Wajib Pajak Yang Memiliki Peredaran Bruto Tertentu.

Akan tetapi surat edaran tersebut masih terdapat permasalahan seperti yang diungkapkan oleh Sudarman (Jurnal STIE Dharma Putra Semarang No. 38/TH.XX/OKTOBER 2013) sebagai berikut: Pajak Penghasilan (PPh) menurut PP 46 adalah bersifat final dengan tarif 1 persen untuk pendapatan yang tidak melebihi $\mathrm{Rp}$ 4.800.000.000,- setahun yang sudah diberlakukan sejak 1 Juli 2013 dan harus sudah mulai pembayarannya paling lambat 15 Agustus 2013. PP 46 ini telah diundangkan pada 13 Juni 2013 oleh Menteri Hukum dan Hak Asasi Manusia Republik Indonesia dan ditindaklanjuti oleh Menteri Keuangan Republik Indonesia dengan menerbitkan Peraturan Menteri Keuangan Republik Indonesia Nomor 107/PMK.011/2013 yang ditetapkan pada 30 Juli 2013 dan baru diundangkan pada tanggal 6 Agustus 2013 serta ditindak lanjuti oleh Direktur Jendral Pajak dengan mengeluarkan Surat Edaran Direktur Jendral Pajak Nomor: SE42/PJ/2013 pada 2 September 2013.

Berawal dari diteribitkannya PP 46 Tahun 2013 sampai dengan penerbitan Surat Edaran Direktur Jendral Pajak ini saja sudah terlihat adanya permasalahan yang timbul di antaranya:

1. Kebijakan Insentif Perpajakan yang tertuang dalam Anggaran Pendapatan dan Belanja Negara (APBN) tahun 2013 yang tertuang dalam UU Nomor 19 tahun 2012 seharusnya PP 46 tersebut sudah dipersiapkan terlebih dahulu sebelum pemberlakuan APBN 2013.

2. Dengan diterbitkannya PP 46 Tahun 2013, PMK Nomor 107/PMK.011/2013 dan Surat Edaran Dirjen Pajak Nomor : SE42/PJ/2013 dari tanggal mulainya pemberlakuan sampai dengan Surat Edaran sangat tidak wajar dan pemerintah 
A. A Supardi \& Ari Samto, Penerapan Peraturan Pemerintah Nomor 46 Tahun 2013...

terkesan memaksakan pemberlakuan PP 46 Tahun 2013 tersebut.

3. Pemberlakuan PP 46 Tahun 2013 belum diikuti kesiapan petugas pajak untuk mengawal keberhasilan dari PP tersebut, hal ini terbukti dari belum siapnya Accounts Representative (AR) diseluruh KPP sampai diterbitkannya SE42/PJ/2013.

4. Pemberlakuan suatu aturan biasanya disosialisasikan terlebih dahulu kepada Wajib Pajak agar Wajib Pajak mengerti dan tergerak untuk melaksanakan aturan tersebut.

5. Pemberlakuan PP 46 Tahun 2013 yang terlihat dipaksakan tersebut membuat Wajib Pajak was-was, karena dengan diundangkannya dan diberlakukannya tersebut sudah terlambat, sehingga Wajib Pajak khawatir dengan denda akibat keterlambatan pembayaran dan kesiapan administrasinya, walaupun akhirnya pemerintah memberikan keringanan pembebasan denda sampai dengan akhir tahun 2013.

Peraturan Pemerintah Nomor 46 Tahun 2013 secara umum masih didapati inkonsistensi hukum pada pasal yang terdapat didalamnya. Menurut Hariyanto dalam jurnal yang berjudul " Inkonsistensi Hukum Pemberian Fasilitas Keringanan Pajak Bagi Usaha Mikro Kecil Menengah (UKM) Melalui Peraturan Pemerintah Nomor 46 Tahun 2013" menjelaskan sebagai berikut:

1. Fasilitas Keringanan UU PPh Untuk Usaha Mikro, Kecil, dan Menengah.

31E UU PPh memberikan keringanan berupa pengurangan tarif sebesar 50\% (lima puluh persen) kepada wajib pajak badan yang memiliki peredaran bruto sampai dengan Rp. 50.000.000.000,-. Pengurangan tarif sebesar $50 \%$ ini diberikan dari tarif sebagaimana Pasal 17 ayat 1 huruf $\mathrm{b}(28 \%)$ dan ayat $2 \mathrm{a}(25 \%)$ yang dikenakan atas penghasilan kena pajak dari bagian peredaran bruto sampai dengan Rp.4.800.000.000,-.

Sayangnya fasilitas pengurangan tarif pajak sebesar $50 \%$ ini hanya dapat dinikmati oleh usaha Mikro, Kecil dan Menengah yang menjalankan usahanya melalui badan usaha dan untuk perseorangan yang menjalankan usaha Mikro, Kecil dan Menengah belum dapat menikmati fasilitas pengurangan tarif pajak ini.

2. Permasalahan PP Nomor 46 Tahun 2013.

Sebelum terbitnya PP Nomor 46 Tahun 2013, diketahui telah ada beberapa fasilitas perpajakan untuk usaha Mikro, Kecil, Menengah yang diberikan oleh UU $\mathrm{PPh}$. Dengan diterbitkannya PP Nomor 46 Tahun 2013, maka bertambah pula fasilitas perpajakan bagi usaha Mikro, Kecil, Menengah. Namun ternyata pemberlakukan PP Nomor 46 Tahun 2013 ini telah menyebabkan beberapa ketentuan dalam UU PPh menjadi tidak dapat dinikmati oleh wajib pajak tertentu.

Beberapa ketentuan tersebut antara lain sebagai berikut:

a. Pasal 7 UU PPh mengeni ketentuan Penghasilan Tidak Kena Pajak (PTKP) yang diperuntukan bagi wajib pajak orang pribadi;

b. Pasal 25 UU PPh mengenai ketentuan angsuran pajak dalam tahun berjalan;

c. Pasal 31E UU PPh mengenai ketentuan pengurangan tarif sebesar $50 \%$ bagi wajib pajak badan.

3. PTKP yang tidak dapat dinikmati berkaitan PP Nomor 46 Tahun 2013.

Pengenaan pajak final sebesar $1 \%$ (satu persen) yang dikenakan dari peredaran bruto setiapbulan berdasarkan PP Nomor 46 Tahun 2013 menandakan bahwa pengenaan pajak penghasilan berdasarkan Peraturan Pemerintah tersebut tidak memperhitungkan pengurangan PTKP dalam pengenaannya. 
Sebelum berlakunya PP Nomor 46 Tahun 2013, PTKP menjadi unsur pengurang untuk menghitung pajak penghasilan orang pribadi. Hak berupa pengurangan ini langsung diberikan berdasarkan UU PPh tanpa membeda-bedakan jenis usaha dari orang tersebut. Sesuai dengan asas hukum Lex Superior Derogat Legi Inferiori (jika terdapat 2 (dua) ketentuan yang saling bertentangan, berarti ketentuan yang lebih tinggilah yang berlaku), maka PTKP harus tetap dapat menjadi pengurangan dalam menghitung pajak penghasilan orang pribadi sekalipun terhadap wajib pajak orang pribadi tersebut diberlakukan PP Nomor 46 Tahun 2013.

4. Angsuran PPh Pasal 25 berkaitan dengan PP Nomor 46 Tahun 2013

Berdasarkan Pasal 25 UU PPh setiap wajib pajak harus membayar angsuran pajak dalam tahun berjalan. Besarnya angsuran pajak setiap bulan adalah sebesar pajak penghasilan yang terutang menurut surat pemberitahuan tahunan pajak penghasilan tahun yang lalu dikurangi dengan pajak penghasilan yang telah dipotong berdasarkan Pasal 21, Pasal 23 , pajak penghasilan yang telah dipungut berdasarkan Pasal 22 dan pajak yang dibayar atau terutang di luar negeri yang boleh dikreditkan berdasarkan Pasal 24 dibagi 12 (dua belas) atau banyaknya bulan dalam bagian tahun pajak. Namun perhitungan angsuran pajak dalam tahun berjalan tersebut, untuk Wajib Pajak Orang Pribadi Pengusaha Tertentu (WPOPPT) berdasarkan pasal Pasal 25 ayat $7 \mathrm{UU} \mathrm{PPh}$ ditentukan paling tinggi sebesar $0,75 \%$ (nol koma tujuh puluh lima persen) dari peredaran bruto.

Dengan mengacu pada ketentuan Pasal 25 ayat 7 UU PPh, maka terlihat bahwa setelah terbitnya PP Nomor 46 Tahun 2013 terjadi penambahan beban pembayaran pajak penghasilan setiap bulan untuk WPOPPT sebesar 0,25\% (nol koma dua puluh lima persen). Meskipun Pasal 25 ayat 7 UU PPh adalah merupakan angsuran pajak dalam tahun berjalan yang pada akhir tahun akan dilakukan perhitungan ulang dan dikenakan tarif berdasarkan Pasal 17 ayat 1a UU PPh, namun tidak berarti bahwa pengenaan pajaknya lebih tinggi jika dibandingkan dengan PP Nomor 46 Tahun 2013 yang mengenakan pajak sebesar 1\% dan bersifat final.

5. Pasal 31E UU PPh Versus PP Nomor 46 Tahun 2013

Sebagaimana yang telah disampaikan dalam fasilitas keringanan dalam UU PPh bahwa wajib pajak badan dengan peredaran bruto sampai dengan Rp.50.000.000.000,- berhak mendapatkan Pengurangan tarif sebesar $50 \%$ yang diberikan dari tarif sebagaimana Pasal 17 ayat 1 huruf b (28\%) dan ayat $2 \mathrm{a}(25 \%)$. Tarif hasil pengurangan tersebut dikenakan atas penghasilan kena pajak dari bagian peredaran bruto sampai dengan Rp. 4.800.000.000,-.

Hal ini menandakan bahwa sejak 1 Juli 2013 terdapat 2 peraturan yang berlaku untuk wajib pajak badan dengan peredaran bruto sampai dengan Rp.4.800.000.000,- (empat milyar delapan ratus juta rupiah). Peraturan tersebut adalah Pasal 31E UU PPh dan PP Nomor 46 Tahun 2013.

Dari aspek keadilan PP 46 Tahun 2013 secara umum belum memenuhi keadilan yang merata dalam hal pemajakan. Dalam artikel Ruston Tambunan dalam website: http://ortax.org/ortax/?mod=issue\&page=sho

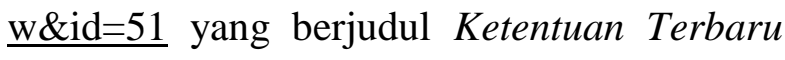


A. A Supardi \& Ari Samto, Penerapan Peraturan Pemerintah Nomor 46 Tahun 2013...

Pajak Penghasilan Atas UMKM: Sederhana Tapi Tidak Adil, menjelaskan bahwa:

a. Ditinjau dari konsep keadilan dalam pemajakan (equity principle), pengenaan $\mathrm{PPh}$ final tidak sesuai dengan keadilan dikarenakan tidak mencerminkam kemampuan membayar (ability to pay). Pemajakan yang adil bahwa semakin besar penghasilan maka semakin besar pula pajak yang harus dibayar.

b. Ini disebut keadilan vertikal atau vertical equity (Musgrave Dan Musgrave, 1976). Penghasilan yang dimaksud disini adalah penghasilan neto, yaitu setelah dikurangi dengan biaya-biaya pengurang penghasilan bruto yang diperkenankan menurut ketentuan perpajakan yang berlaku (Mansury R, 1996). Berhubung $\mathrm{PPh}$ Final dihitung langsung dari peredaran bruto maka pemajakan tersebut tidak sesuai dengan konsep keadilan dalam pemajakan. Betapa tidak, besar kecilnya penghasilan neto seseorang atau badan usaha tidak akan mempengaruhi besarnya pajak yang akan dibayar karena pajak dihitung dengan mengalikan tarif langsung terhadap peredaran bruto. Bahkan dalam keadaan rugi pun, dengan pengenaan $\mathrm{PPh}$ Final seseorang atau badan usaha tetap harus membayar pajak.

Penjelasan-penjelasan yang diuraikan oleh peneltian terdahulu dan sumber-sumber lain yang terpercaya yang diambil oleh penulis, maka dapat disimpulkan oleh penulis bahwa pelaksanaan PP 46 Tahun 2013 dengan Undang-Undang Perpajakan yang berlaku secara umum, belum sesuai dengan peraturan perpajakan yang berlaku.

Undang-Undang Ketentuan Umum Dan Tata Cara Perpajakan adalah merupakan dasar perpajakan yang fundamental yang menjadi panduan dari peraturan-peraturan pajak yang lainnya. Pasal-pasal dalam UU KUP sudah mengalami perubahan, perubahan terakhir adalah dengan terbitnya Undang-Undang Nomor 16 Tahun 2009. Dalam undang- undang ini dijelaskan secara rinci dan jelas mengenai peraturan yang ditujukan kepada masyarakat dalam hal ini adalah Wajib Pajak mulai dari pengertian pajak sampai dengan sanksi dan prosedur dalam pemenuhannya dalam pembayaran pajak kepada negara.

Dari uraian mengenai peraturan pajak yang ada di Indonesia dengan ini penulis akan memaparkan bahwa terdapat 3 unsur pajak, yakni pajak harus memenuhi kriteria sebagai berikut:

1. Kebijakan Pajak (Tax Policy)

Kebijakan perpajakan yang akan memberikan pengaruh pada undangundang pajak yang disusun dan selanjutnya akan menentukan administrasi pajak yang akan digunakan dan akan berlanjut menjadi kebijakan perpajakan yang akan diambil di masa yang akan datang.

Dalam PP 46 Tahun 2013 peraturan ini masih bersifat abu-abu karena masih terdapat ketidakwajaran dan ketidakadilan atas pemberlakuan peraturan tersebut.

Kebijakan PPh Final 1\% yang tertuang dalam PP 46 Tahun 2013 tidak sesuai dengan asas keadilan perpajakan. Asas keadilan yang dilanggar antara lain pertama kebijakan ini tidak mempertimbangkan kemampuan ekonomis dari objek pajak, sebab dipotong dari omzet bukan dari margin. Kedua kebijakan ini melanggar konsep PTKP sebagai biaya minimal untuk bertahan hidup sesuai dengan PMK 122/PMK.010/2015 mengenai penyesuaian besarnya PTKP. Ketiga kebijakan ini tidak memberi ruang bagi Usaha Mikro Kecil Menengah (UMKM) yang menderita kerugian untuk dapat membebankan kerugiannya dan tetap dipajaki.

2. Undang-Undang Pajak (Tax Law)

Kita menyadari bahwa kenyataannya di mana pun tidak ada undang-undang yang mengatur setiap permasalahan secara 
sempurna, maka dalam pelaksanaannya selalu diikuti oleh ketentuan-ketentuan lain (Peraturan Pemerintah Keputusan Presiden, Keputusan digunakan Menteri Keuangan dan Direktur Jendral Pajak), maka tidak jarang ketentuan pelaksanaan tersebut bertentangan mencapai tujuan yang lain yang ingin dicapainya. Keadaan ini menyebabkan munculnya celah (loopholes) bagi Wajib Pajak untuk menganalisis dengan cermat atas kesempatan tersebut untuk perencanaan pajak yang baik.

PP 46 Tahun 2013 dilihat dari perspektif Undang-Undang Pajak (Tax Law) masih terdapat kelemahankelemahan pada beberapa pasal yang terdapat pada peraturan tersebut, sehingga dengan mudah kelemahan ini dijadikan celah untuk melakukan pelanggaran dari Wajib Pajak yang menggunakan peraturan ini.

3. Administrasi Pajak (Tax Administration)

Indonesia merupakan negara yang begitu luas wilayahnya dan begitu banyak penduduknya, dan sebagai negara yang sedang membangun (developing country) masih mengalami kesulitan dalam melaksanakan secara memadai (property). Hal yang mendorong perusahaan untuk mengabaikan dan tidak ingin memenuhi kewajiban pajaknya hal ini dikarenakan begitu luasnya peraturan perpajakan yang berlaku dan sistem informasi yang belum efektif.

PP 46 Tahun 2013 dilihat dari perspektif administrasi pajak masih didapati adanya diskriminasi perlakuan atas kompensasi kerugian dan pengurang pajak yang bisa dikreditkan.

Peraturan Pemerintah Nomor 46 Tahun 2013 yang sudah diterbitkan dan sudah dilaksanakan oleh Wajib Pajak baik orang pribadi maupun badan yang mempunyai peredaran bruto kurang dari Rp.4.800.000.000,- ini masih terdapat beberapa dampak yang cukup signifikan yang harus diperhatikan oleh pembuat kebijakan pajak agar kebijakan tersebut menjadi kebijakan yang tidak memberatkan bagi salah satu pihak.

Berikut ini adalah dampak yang disebabkan atas pemberlakuan Peraturan Pemerintah Nomor 46 Tahun 2013 bagi Wajib Pajak yang menggunakan acuan peraturan ini sebagai pemenuhan kewajiban pajak, antara lain adalah sebagai berikut:

1. Kerugian dari usaha, tetap dikenakan tarif $1 \%$ dari omzet

Seharusnya Peraturan Pemerintah Nomor 46 tahun 2013 yang ditetapkan menjadi pajak final ini didukung oleh Peraturan Menteri Keuangan untuk mengatur perkecualian yang tidak dapat dijangkau oleh Peraturan Pemrintah Nomor 46 ini. Misalnya kerugian yang diderita oleh perusahaan, karena bersifat pajak final sehingga biaya usaha tidak dapat menjadi pengurang penghasilan kena pajak padahal biaya usaha lebih besar daripada penghasilan yang didapatkan.

Kerugian merupakan hal yang lazim dalam dunia usaha sehingga perlu aturan khusus untuk memperlakukan pengusaha yang mengalami kerugian. Bentuk dari aturan khusus ini setidaknya membebaskan dari tarif 1\% Peraturan Pemerintah Nomor 46 Tahun 2013 untuk pengusaha yang mengalami kerugian usaha (dengan syarat mampu membuktikannya) ataupun bahkan mendapat kompensasi kerugian yang bisa di kompensasikan untuk masa pajak berikutnya. Hal ini akan lebih dekat dengan keadilan dan sesuai dengan asas 
A. A Supardi \& Ari Samto, Penerapan Peraturan Pemerintah Nomor 46 Tahun 2013 ...

equity yang disampaikan oleh Adam Smith.

2. Mengubah perilaku dunia usaha

Peraturan Pemerintah Nomor 46 tahun 2013 akan mempunyai dampak yang tidak bisa dihindari, karena setiap kebijakan akan mempunyai dampak positif maupun dampak negatif. Kecenderungan negatif dari pengusaha akan menurunkan tarif atau menjaga omzet untuk tidak melebihi omzet dari Rp.4.800.000.000,-. Hal ini tentunya akan merugikan negara karena akan menurunkan pendapat negara dari yang seharusnya diterima.

Pengusaha akan melakukan tax planning atas peraturan ini, bagaimana bisa menghindari pajak (tax avoidance) untuk mendapatkan insentif tersebut. Misalnya pengusaha akan menutup usaha pada bulan desember karena omzet usahanya sudah mencapai Rp.4.700.000.000,- tentunya perilaku ini merugikan konsumen dan bahkan perekonomian. Dengan cara demikian pengusaha akan mendapatkan tarif pajak yang murah untuk memanfaatkan peraturan tersebut.

3. Peraturan PP 46 Tahun 2013 yang bersifat abu-abu masih menyisakan kelemahankelemahan dari sisi kekuatan hukum yang di dalamnya sehingga berdampak pada banyaknya celah-celah bagi wajib pajak untuk melanggar peraturan tersebut.

4. Ketidak adilan dalam peraturan ini sangat menonjol terlihat dari adanya diskriminasi-diskriminasi perlakuan Wajib Pajak yang tampak pada tidak adanya perlakuan khusus pada Wajib Pajak yang mengalami kerugian, tidak adanya pengurangan pajak seperti kredit pajak dan PTKP dan lain sebagainya.

\section{SIMPULAN DAN SARAN}

Berdasarkan hasil penelitian, pembahasan dan interpretasi yang telah diuraikan pada bab-bab sebelumnya, dengan mengacu pada beberapa teori dan hasil penelitian sebelumnya, maka peneliti dapat menarik kesimpulan sebagai berikut:

1. PT Global Bintang Utama Jakarta dalam pemenuhan kewajiban perpajakan sudah pernah menggunakan acuan PP 46 Tahun 2013 pada tahun pajak 2013 dan 2014 untuk dasar pengenaan kewajiban pajaknya, dan akan digunakan kembali pada tahun pajak 2016 mengingat pada tahun 2015 omzet yang didapatkan oleh perusahaan mengalami penurunan yang menjadikan peredaran bruto dibawah kategori peredaran bruto PP 46 Tahun 2013 yakni di bawah Rp.4.800.000.000,per tahun.

2. PT Global Bintang Utama dalam pemenuhan kewajiban perpajakan pernah menggunakan acuan tarif pajak penghasilan Undang-Undang Pajak Penghasilan Nomor 36 Tahun 2008 yaitu dengan menggunakan tarif PPh Pasal 31E pada tahun 2015 yang mengakibatkan beban pajak menjadi lebih besar atau tinggi.

3. Peraturan Pemerintah Nomor 46 Tahun 2013 secara umum belum sesuai dalam pelaksanaannya dengan Undang-Undang Nomor 36 Tahun 2008 dan UndangUndang Nomor 28 Tahun 2007.

Saran yang dapat diberikan adalah sebagai berikut:

1. PT Global Bintang Utama sebaiknya mengajukan ke KPP untuk menggunakan PP Nomor 46 Tahun 2013 sebagai dasar perhitungan, penyajian, pelaporan terkait pajak pada tahun pajak 2016 mengingat omzet tahun pajak 2015 masih di bawah Rp.4.800.000.000,- setahun.

2. Sebaiknya sosialisasi mengenai peraturan perpajakan didahului dengan surat edaran pelaksanaan peraturan sebelum peraturan tersebut diterbitkan dan digunakan oleh Wajib Pajak atau PKP. 
3. Pembuat kebijakan pajak seharusnya dapat memberikan kemudahan dan kejelasan mengenai kebijakan pajak yang akan diberlakukan dengan melakukan evaluasi terhadap PP Nomor 46 Tahun 2013.

\section{DAFTAR PUSTAKA}

Anjarwati, Ratna. 2015. PPH Final 1\% Untuk UMKM. Yogyakarta: Pustaka Baru Press.

BPPK Kemenkeu. Penghitungan Penghasilan Neto (NPPN) Sebagai Sarana Penghitungan Pajak Secara Jabatan Dalam Pemeriksaan Pajak. http://www.bppk.kemenkeu.go.id/publi kasi/artikel/167-artikel-pajak/20965norma-penghitungan-penghasilan-netonppn-sebagai-sarana-penghitunganpajak-secara-jabatan-dalampemeriksaan-pajak. Diakses 02 April 2016.

Dwi Anggoro, Damas. 2013. Analisa Peraturan Pemerintah Nomor 46 Tahun 2013.

https://damasmart.wordpress.com/2013/ 11/17/analisa-peraturan-peme rintahnomor-46-tahun-2013/. Diakses 02 April 2016.

Mansury. 1994. Panduan Konsep Utama Pajak Penghasilan Indonesia. Jakarta: Bina Rena Pariwara.

Mardiasmo. 2011. Perpajakan Edisi Revisi 2011. Yogyakarta: Penerbit Andi.

Pohan, Anwar, Chairil. 2013. Degradasi Fungsional Norma Penghitungan Penghasilan Neto (Sebagai Implikasi Dari Peraturan Pemerintah Tentang Pajak Penghasilan Dari Usaha Wajib Pajak Yang memiliki Peredaran Bruto Tertentu) Yang Berdampak Pada Ketidakadilan Pajak. Jakarta: Institut Ilmu Sosial dan Manajemen STIAMI.
Peraturan Pemerintah Nomor 46 Tahun 2013 Tentang Pajak Penghasilan Atas Penghasilan dari usaha yang diterima atau diperoleh Wajib Pajak yang memiliki peredaran bruto tertentu.

Rahman, Abdul. 2010. Panduan Pelaksanaan Administrasi Perpajakan Untuk Karyawan, Pelaku Bisnis Dan Perusahaan. Bandung: Nuansa.

Resmi, Siti. 2016. Perpajakan Teori dan Kasus. Jakarta: Salemba Empat.

Rosdiana, Haula dan Edi Slamet Irianto. 2011. Panduan Lengkap Tata Cara Perpajakan di Indonesia. Jakarta: Visimedia Pustaka.

Sugiyono. 2014. Metode Penelitian Kuantitatif Kualitatif Dan $R \quad \& \quad D$. Bandung: CV Alfabeta.

Sindari, Dianaswara dan Arniati. 2013. Analisis Perbandingan Penerapan Peraturan Pemerintah 46 Tahun 2013 dengan Undang-Undang Nomor 36 Tahun 2008 Pada PT Trio Infotek Batam. Batam: Politeknik Negeri Batam.

Sudarman. 2013. Peraturan Pemerintah Republik Indonesia Nomor 46 Tahun 2013 (PP -46/2013) Dan Permasalahannya. Semarang. STIE Dharama Putra Semarang (Dharma Ekonomi-No. 38/TH. XX/ OKTOBER 2013).

Syahdan, Anuar, Saifhul dan Asfida Parama Rani. 2013. Dimensi Keadilan Atas Pemberlakuan Peraturan Pemerintah Nomor 46 Tahun 2013 Dan Peningkatan Kepatuhan Wajib Pajak. Banjarmasin: STIEI Kayutangi (Jurnal Infestasi Vol. 10 No. 1 Juni 2014 Hal: 64-72).

Surat Edaran Direktur Jenderal Pajak SE. 42/PJ/2013 Tentang Pajak Penghasilan Atas Penghasilan Dari Usaha Yang 
A. A Supardi \& Ari Samto, Penerapan Peraturan Pemerintah Nomor 46 Tahun 2013...

Diterima Atau Diperoleh Wajib Pajak Yang Memiliki Peredaran Bruto Tertentu.

Tambunan, Ruston. 2013. Ketentuan Terbaru

Pajak Penghasilan Atas UMKM: Sederhana Tapi Tidak Adil. http://ortax.org/ortax/?mod=issue\&page =show\&id=5.Diakses 02 Apri 2016.

Undang-Undang Nomor 6 Tahun 1983 sebagaimana telah beberapa kali diubah terakhir dengan Undang-Undang Nomor 16 Tahun 2009 Tentang Ketentuan Umum dan Tata Cara Perpajakan.
Undang-Undang Nomor 7 Tahun 1983 sebagaimana telah beberapa kali diubah terakhir dengan Undang-Undang Nomor 36 Tahun 2009 Tentang Pajak Penghasilan.

Yanto, Hari. 2014. Inkonsistensi Hukum Pemberian Fasilitas Keringanan Pajak Bagi Usaha Mikro Kecil Menengah (UMKM) Melalui Peraturan Pemerintah Nomor 46 Tahun 2013. Bandung: Universitas Katolik Parahyangan (E-Journal Graduate Unpar Part B : Legal Science Vol. 1, No. 2 (2014). 